SHS Web of Conferences 10, 00014 (2014)

DOI: $10.1051 /$ shsconf/20141000014

C Owned by the authors, published by EDP Sciences, 2014

\title{
Intergenerational solidarity in family communication and childrearing among Russians living in Estonia
}

\author{
I. Järva \\ Tallinn University, Estonia
}

\begin{abstract}
The aim of this research was to ascertain the importance of intergenerational solidarity in communication within the family and childrearing among the Russians living in Estonia.

Generations see the world differently enough. One of the reasons for that is individualistic worldview which characterizes not only the younger generation, but individualistic tendencies have percolated into other generationsas well. All generations admit the presence of a generation gap, but they disclaim presence of intergenerational conflict. At the same time respondents affirm that there is solidarity between generations in their families and it is based on love and respect. Solidarity between generations in families is revealed both on spiritual level (communicating, love, trust, mutual understanding, common interests) as well as in real help given by generations to each other as far as homework, children's upbringing, and economical aid are concerned.
\end{abstract}

\section{Introduction}

The end of the $20^{\text {th }}$ century was the era, when the background of social institutions and norms of behaviour in a very short time were changed. The process of changes in Estonia most of all concerned the Russian community, whose social mobility has considerably increased within the last generation in comparison to Estonians, as before the restoring of the independence of Estonia the part of factory workers was a half of adult population ${ }^{1}$. The culture of younger generation is characterised by cultural pluralism: westernisation, ethnic cultural influences ${ }^{2}$, virtual culture ${ }^{3}$, it has been spoken about the Blip culture ${ }^{4}$, the Third Wave culture (Toffler op. cit.), anti-culture and socio-cultural kitsch ${ }^{5}$. In many ways it meant repelling the earlier cultural heritage whereby "in comparison with traditional culture, mechanisms, forms of existence as well as functioning of the culture transformed."6

\footnotetext{
${ }^{1}$ Tammaru, T. Venelased Eestis: ränne ja kohanemine. Tallinn: Sisekaitseakadeemia, 1999: 35.

2 Кастельс М. Информационная эпоха. Экономика, общество и культура. Москва: CEU, 2000: 36.

${ }^{3}$ McLuhan, M. The Guttenberg Galaxy: the Making of Typographical Man. Toronto: University of Toronto Press, 1995.

${ }^{4}$ Toffler, A. The Third Wave. Toronto, NY, London, Aukland: Baantam Books, 1982: 165-167.

5 Ровнер А. Третья культура. Санкт-Петербург: Медуза, 1996: 86.

${ }^{6}$ Самохвалова В.И. Образ культуры минувшего века. Доминанты и тенденции. Век XX анфас и профиль: Размышления о столетии, ставшем историей. Москва: Новый Век, 2001: 404 .

This is an Open Access article distributed under the terms of the Creative Commons Attribution License 4.0, which permits unrestricted use, distribution, and reproduction in any medium, provided the original work is properly cited.
} 
SHS Web of Conferences

\section{Literature}

The research is based on a socio-cultural approach, which allows education to be seen from two aspects - the educational environment as a system of meanings, and signs and social relations. The historical nature of human reality sheds light upon Ortega y Gasset's (2011) notion that a generation entails a horizontal reference to living individuals as being "contemporaries"; and it refers to the vertical differentiation, in age, between youth, maturity, and old age-in short, as being "coevals."

According to the mechanism of generation development, the conflict between generations is a usual course of the (non-pathological) historical progress. It is a universal socio-psychological mechanism, which accompanies as softly and painlessly as possible, because the asynchronisation of generation is a negative and socially dangerous phenomenon. Asynchronism disturbs the consolidation of society and interferes with its emotional climate and the result of discussions ${ }^{7}$. To avoid the breakdown of society, asynchronism is necessary through cohorts and generations synchronization, which denotes contact opportunities of two different personality types ${ }^{8}$.

Intergenerational solidarity is best understood within the context of shared expectations and obligations regarding the ageing of individuals and the succession of generations ${ }^{9}$. M. Silverstein and V. L. Bengtson have codified six principal dimensions of solidarity between generations. These dimensions comprise (1) structure (factors, such as geographic distance, that constrain or enhance interaction between family members), (2) association (frequency of social contact and shared activities between family members), (3) affection (feelings of emotional closeness, affirmation, and intimacy between family members), (4) consensus (actual or perceived agreement in opinions, values, and lifestyles between family members), (5) function (exchanges of instrumental and financial assistance and support between family members), and (6) norms (strength of obligation felt toward other family members) ${ }^{10}$.

Home education gives perspective opportunity to explore the synchronization/asynchronisation process among generations. Upbringing shapes the values in the society, being also their mirror. There are different generations participating in the breeding, which also gives an opportunity to observe the solidarity forms, contacts and emotional connection between generations.

Upbringing is a bilateral process, which is the result in which not only the children but also their parents change. On the other hand, upbringing as a socio-cultural occurrence does not exist alone, but is related to society's socio-cultural factors. The socio-cultural speciality of upbringing reality is determined by the motives of educational acts. Cultural philosopher Alfred Schultz distinguished two motives in every social act: in-order-to and because of, which have different meanings: the first is part of integral act, the other asks for reflection, analysis and meditation ${ }^{11}$. According to M. Weber ${ }^{12}$, the motives of social reality are based on purposes, values, emotions and traditions. Maslow complements Weber, saying that motives shape people's behaviour not by themselves, but through their needs ${ }^{13}$.

Based on parents' educational motives, a picture of upbringing is turning out. It is temporally and substantially wider than it is at the here-and-now. In traditional cultures, the upbringing motives are based on the past: cultural and family traditions. On the other hand, the motives are directed to a

\footnotetext{
7 Толстых А. Опьт конкретно-исторической психологии личности. Санкт-Петербург: Алетейя, 2000: 154

8 Ibid: 18.

${ }^{9}$ Bengtson, V.L., Oyama P.S. Intergenerational Solidarity: Strengthening Economic and Social Ties. New York: United Nations Headquarters, 2007.

10 Silverstein, M. \& Bengtson, V.L. Intergenerational Solidarity and the Structure of Adult Child-Parent Relationships in American Families. American Journal of Sociology, 1997: 432.

11 Schutz, A. Collected papers, II. Studies in social theory. A. Brodersen (ed.). Hague: Martinus Nijhoff, 196411

12 Weber, A. (). Võimu ja religiooni sotsioloogiast. Vagabund, 2002: 38.

13 Maslow, A.H. Motivation and personality. $2^{\text {nd }}$ ed. New-York: Harper \& Row Publishers, 1970.
} 


\section{Int. Conf. SOCIETY. HEALTH. WELFARE.}

(imaginary) child's cultural future, which parents interpret according to their cultural past ${ }^{14}$. In a drastic and quickly changing society the vision of a child's future motives are actualizing in public minds, where the traditional and cultural meaning and experience are lost and not corresponding to time.

Childrearing in Russian traditional upbringing culture encompassed family, relatives, neighbours, children's subculture, strangers and even lifestyle as a whole. A child acquired contextual and situational competence through early obligations, tight personal relations with the community and continuous communication; becoming a part of traditional society and formation of a collective scale of values demanded as a primary aim the precise acquisition of the correct guiding principles for life, rules of behaviour and social norms. Grandparents had an essential role in the upbringing of children. They were the link between different periods of time - an emotional and spiritual environment of communication for children ${ }^{15}$ (Громыко 1991, 143).

The changes that occurred in the upbringing environment 10 years ago would explain much about the gap between generations. The greatest transformation took place in the younger generation, which may be called both the generation of de-industrialization and the generation of the Great Break. In my doctoral thesis ${ }^{16}$, was put up a purpose to analyze and compare education of children in Russian families of Estonia over three generations.

The results of the research on two generations can be generalized in a table (Table 1).

Humanistic values as ideals of outlook on life also apply to the younger generation, but they have changed more abstractly. They do not have very much deepness; hence the humanistic symbols have become signs that carry less meaning. According to that, solidarity, altruism and sacrificial mentality as the highest values have lost their meaning before an individual autonomy and its free growth.

Contrary to the less varying, stable environment, being in the middle generation, a modernday, mobile environment needs education and upbringing, which are able to retrain according to the environment challenges. This emphasises the importance of new attitudes - creativity, enterprise and mobility, - whose development is taking place through business games at home. Children's almost limitless freedom in behaviour, clothing and giving opinion is replacing the obedience borders with pedagogy. In young generation the positions are limited with their parents' authority, which is in children's eyes doubtable in content and form. The public position is carrying a bigger role in the content of authority.

On the other hand, parents' authoritarianism is substituted by the parental relationships between a child and a parent. Democracy marks the family culture between parents and children. Russian family largely accepted the standards that were characteristic to general Western European family: tendency of emancipating and women's high educational status.

The emotional communication with a child is decreasing and is replaced by rational approach and its development. The narrative culture (family mythology, communication inside the family, fairy-tales, songs, large-family syndrome) in family life is not only changing the communication inside the family but also the contacts outside of the family. Thus, the emotional moment is declining in the family.

The conception of education has changed. While in former times education appeared to be a target, the terminal value, a mental luggage giving psychological well-being, nowadays it is an instrumental value, whereby the acquisition of languages and education is an investment in achieving social security in the future. Kindergarten has acquired a new function - offering educational service and training. High involvement of parents at work does not allow them to take their children to extra classes, thus they prefer having the services of speech therapists, orthopaedist, sports section, computer training offered by the

\footnotetext{
14 Коул М. Культурно-историческая психология. Наука будущего. Москва: Когито-Центр. Институт психологии РАН, 1997: 212.

15 Громыко М. Мир русской деревни. Москва: Молодая Гвардия, 1991: 143.

16 Järva, I. Põlvkondlikud muиtused vene perekondade kasvatuses: sotsiokultuuriline käsitus. Tallinna Pedagoogikaülikool Sotsiaalteaduste Dissertatsioonid 9 TPÜ Kirjastus, 2004.
} 


\section{SHS Web of Conferences}

Table 1. Educational-paradigmatic changes in the younger generation (Järva 2004, 105).

\begin{tabular}{|c|c|}
\hline MIDDLE GENERATION & YOUNGER GENERATION \\
\hline Humanistic values as ideals of world view & $\begin{array}{l}\text { Transformation of higher humanistic values into } \\
\text { abstract ideals }\end{array}$ \\
\hline Socio-centrism & Anthropocentrism \\
\hline Solidarity, altruism, self-sacrifice as higher values & Autonomy of a personality as a value \\
\hline Traditions, stability & Innovation, mobility \\
\hline Minimisation of needs & Hedonism \\
\hline Passivity / Success psychology & Achievement psychology \\
\hline Authority pro authoritarianism of parent & $\begin{array}{l}\text { The authority of the parent is questioned by the child } \\
\text { because of its content and its form. Parity relations } \\
\text { between the child and parent. }\end{array}$ \\
\hline Restriction of child's freedom, obedience & $\begin{array}{l}\text { (Unrestricted) freedom in behaviour, clothing, } \\
\text { opinions }\end{array}$ \\
\hline Moral and patriotic substance in upbringing & $\begin{array}{l}\text { Abundance of material factors as indicators of the } \\
\text { care of parent, also in rewards and punishments } \\
\text { carried out by parent }\end{array}$ \\
\hline Emotional & Rational \\
\hline Non-pragmatic approach & Utilitarian approach \\
\hline Education as the terminal value & Education as instrumental value \\
\hline Endogenous factors prevail & Exogenous factors prevail \\
\hline Reflecting future professions in children's play & $\begin{array}{l}\text { Reflecting work in children's play and in future } \\
\text { imaginations as symbol of power and material well- } \\
\text { being }\end{array}$ \\
\hline $\begin{array}{l}\text { Family has the function of upbringing. Kindergarten } \\
\text { is a place where the parent goes for festive events and } \\
\text { is not interested in its activities }\end{array}$ & $\begin{array}{l}\text { Professional nature of education. New function of } \\
\text { kindergarten as a provider of education pro training. } \\
\text { The parent is interested in the activities and less visits } \\
\text { festive events }\end{array}$ \\
\hline $\begin{array}{l}\text { Family culture as a narrative culture (family } \\
\text { mythology, interaction within the family, fairy tales, } \\
\text { songs, books, extended family syndrome) }\end{array}$ & $\begin{array}{l}\text { Decrease in interaction within the family as well as } \\
\text { outside the family. At the same time increase in the } \\
\text { importance of the family as a factor of psychological } \\
\text { and emotional satisfaction }\end{array}$ \\
\hline $\begin{array}{l}\text { Children's subculture being passed down from } \\
\text { generation to generation and a world view created } \\
\text { by children themselves }\end{array}$ & Children's culture, which has been created by adults \\
\hline Picnics and walks in nature as family traditions & $\begin{array}{l}\text { Emergence of new family traditions such as family } \\
\text { visits to McDonald's restaurants }\end{array}$ \\
\hline
\end{tabular}

kindergarten. The role of kindergarten at providing education grows so rapidly that we can speak about a new tendency in childrearing - upbringing is becoming professional.

The meaning of children subculture has changed. When the last generations got their picture of the world from generation to generation and children created it themselves, then nowadays the children subculture is created by adults and portrays itself as a part of commerce culture (mass culture, virtual and playing culture).

Opposite to the middle generation, success psychology, where success depends on hard work, there is achievement psychology amongst young generation, where the success depends on lucky chances instead of great effort. Limiting needs are replaced with hedonic attitude of consuming pleasure. In that case, the product has more often a meaning of consumer's status than a consuming value. Children's games and future perception are other factors that reflect the importance of materialistic elements. The work appears to be the symbol of power and physical welfare. Materialistic factors are emphasized in punishment and promotion methods as well as in parental care. There are also some materialistic 


\section{Int. Conf. SOCIETY. HEALTH. WELFARE.}

factors in family traditions. When in the middle generation picnics and walks in the nature played a remarkable role, nowadays visiting McDonald's and fancy restaurants with the whole family can be considered as new family traditions. The spread of materialistic factors occurs due to many reasons. The new generation has to solve the utilitarian problems and they also have to find their niche. Secondly, the sacred patriotism and morality, that have always fed Russian upbringing and according to which it had to raise motherland worth citizens, is fading.

Getting acquainted with generation studies in former republics of the Soviet Union as well as in the countries of Eastern Europe it appears that post-socialist countries (with the exception of Eastern Germany) have materialistic orientation, which contrasts with the development of Western Europe after $1976^{17}$. Materialistic tendencies and pragmatism of world view began to emerge in Eastern Europe at the end of the 1970s, when the status of intellectual professions was devalued and a new ideology of work was formed, in which salary played a more important role than the content of work. Therefore highly qualified specialists became workers, waiters and cooks. The place of education as the determiner of social status was taken by personal connections and acquaintances ${ }^{18}$. On the other hand, there is hope that children, who have grown up in the conditions of satisfying material needs, will according to Inglehart's theory ${ }^{19}$ begin to appraise not so much material as post-material values.

\section{The aim}

The research, conducted in 2012, is a logical continuation of the author's research conducted in $2004^{20}$, and it is tries to answer the questions such as: how have the children turned out while raised according to the certain educational model; are they close and how close are they to their parents and, what forms the foundation of the intergenerational communication among the Russians living in Estonia: is it stability or change, continuity or scission, conflict or solidarity?

The aim of this research is to ascertain the importance of intergenerational solidarity in communication within the family and childrearing among the Russians living in Estonia.

The method of gathering information was group interviews. The sample of the study was comprised by 102 respondents. Amongst the people in younger generation (age 19-28) there were 6 focus group interviews carried through; in middle generation 4 focus group interviews and in older generation 3 focus group interviews. The focus group consisted of 7-9 respondents. In the period of the interviews people in the younger generation group were 19-28 years old, in the middle generation group 30-45 and older generation 46-65 years old. For the author it was important to originate from the generation's anthropological status: the respondents from the older generation were grandmothers, people from the middle generation were mothers and respondents from the younger generation were childless or with children up to kindergarten age. The group interviews were carried out in March-September of 2012.

17 Туманов С. В. Культурные миры молодых россиян: три жизненные ситуации. Москва, МГУ, 2000; Коровицина Н. Среднее поколение в социокультурной динамике Восточной Европы второй половины XX века. Москва: Логос, 1999; Kovacz, D. \& Maggard, S.W.. The Human Face of Political, Economic and Social: Change in Eastern Europe. - East European Quaterly, 1993, 3; Kraav, I. Väärtused erinevate põlvkondade elus. - Väärtuskasvatus. Tartu Ülikooli pedagoogika osakonna väljaanne nr. 6. Tartu, 1998: 87.

18 Коровицина Н. Среднее поколение в социокультурной динамике Восточной Европы второй половины XX века. Москва: Логос, 1999: 46-56.

${ }^{19}$ Inglehart, R. (1971). The Silent Revolution in Europe: Intergenerational Change in Post-Industrial Societies. American Political Science Review, Vol. LXV, No. 4, Dec.: 991-1019.

20 Järva, I. Põlvkondlikud muutused vene perekondade kasvatuses: sotsiokultuuriline käsitus. Tallinna Pedagoogikaülikool Sotsiaalteaduste Dissertatsioonid 9 TPÜ Kirjastus, 2004. 
SHS Web of Conferences

\section{Results of research}

All generations talk about their affiliation to their family and clan with pride. In all three generations, the issues least mentioned were the relations with the people they need and taking care of themselves. Bright life was only important for younger generation. Despite the fact that religion received a low position amongst the respondents, half of the people in the younger generation and $3 / 4$ in the middle generation claimed to believe in God. However, only $1 / 10$ of the respondents attend church. The respondents explained the situation by saying that their connection with God is personal and they cannot relate it with any certain confession. On one hand, it can be interpreted as individualism, but on the other hand the religion culture broke during the Soviet time, when parents did not go to church and did not teach it to their children either.

It was important to know, what kind of emotional relations each generation had in the families. Most of the people from the older generation answered that they were always open for communication with other generations but sometimes their time is limited. In the middle generation there were $2 / 3$ of the people who believed them to be open communicators. But there were only one third of those people who claimed that they had time as well as desire to communicate with people from the younger generation. The main obstacle in communication was lack of time. There was only one respondent in the middle generation, who had enough time for communication but there was no desire for communication. But at the same time one fifth of the younger generation did not have a need for communication with older generations. Also, one tenth of the younger generation affirmed the fact that they do not have trustworthy reciprocal communication level in their family. Although this tendency is weak, a certain protest against parents amongst the younger generation can be seen.

The older generation says that they see the main life problems similarly with their adult children. This does not fully apply to the middle and younger generation, where only one third of the middle and a half of the younger generation see things similarly with their parents. At the same time one third of the younger generation claims that their parents' outlook on life reflects yesterday: they can be understood, but their advice does not have to be overtaken. The middle generation takes those differences with calmness. More than half of the respondents explain it by saying that those variances were mainly related to the puberty years and are now fading. Almost one fifth of the respondents think that those misunderstandings started to disappear when their children were having their own children.

If we later look back at the upbringing that was given to the children, we can see similarities in the middle and older generations. Grandparents claim that if they had had a need to change anything, they would have paid more attention to understanding the nature and they would have paid less attention to patriotism. The middle generation is also satisfied with the upbringing given by older generation and with the raising methods they used on their children. If they had had an opportunity to start again, they would have taken modesty and their words into account. The younger generation has much more critics towards their parents. They wish they had learned more about thinking independently, compromising, education and modesty instead of being a patriotic and upstanding citizen.

The generation of grandparents believes themselves to be hard-working, honest, modest and conscientious. Other generations think their main characteristics are sweet-temper, civility, caring for people and then hard work. The younger generation can see experience, loyalty, helping and selfdiscipline in their grandparents. $3 / 4$ of the interviewed youth stated that their grandparents did not systematically take part in their upbringing. But at the same time the youth consider their relations with the older generation to be more harmonious than with their own generation or even with their own brothers and sisters. It is interesting that a quarter of the younger generation did not find any flaws in the older generation. That proves honouring and compatible relationships with grandparents. There were some negative characteristic features that the middle generation pointed out about the older generation: passivity; disability of defending their opinion, compromising and adapting to unfamiliar situations. The younger generation is bothered by the fact that their grandparents get into "hot water" in daily situations, but at the same time young people are tedious and too perfect. 


\section{Int. Conf. SOCIETY. HEALTH. WELFARE.}

The middle generation thinks that they are conscientious, honest, erudite, mobile and honour the older generation. The middle-aged complained about self-esteem, because they do not know how to say "no", they do not have enough time to rest, they trust people too easily. They are also pretty clumsy in technology: every new version of Microsoft Word springs up inferiority complex and estrangement from reality in them. The older generation emphasizes the eruditeness, compromise and competitiveness amongst the middle-agers. But they also see negative characteristics such as overworking, self-sacrifice and lack of patriotism. Young people think that their parents are kind-hearted and loving people, who can easily find compromise; they are educated and they honour older people. At the same time they do not dress fashionably, they are too conservative, allowing themselves little entertainment. They also do not manage technology and they are sometimes inflated.

The younger generation believes themselves to be successful, smart, purposeful and useful for the society. They also think that they have well-developed communication skills and independent thinking and they have a knack of technology. They confess that they do not keep their word; they are coarse, egoistic, too rational, rather communicate with the TV set and computer than with a book; they do not honour people older than themselves; and their behaviour verges from one extremity to another (aggression versus stress). The middle generation can see perseverance, valuing freedom, mobility, goodness and openness in the younger generation that has become independent much earlier than they did. Parents think that their adult children are very rational at many levels: they trust technology rather than their intuition; they do not keep their word; they value material qualities; they do not honour older people. The parents feel that they can be blamed for all of those changes, saying that there was too little communication in the family.

The older generation beholds the younger generation as an active, open-minded and mobile generation, without complexes, which has unprecedented opportunities for education; which not only manage the technology but also the fast changing world around them. $4 / 5$ of the older generation see wisdom, which needs deeper research, in younger people. They are jealous of the young people who are courageous to take responsibilities and make decisions independently and do not fear hardships. They also mark the desire for adventure in young generation's action; it is good for their courage and creativity. There are four grandmothers who claim that they owe all the knowledge to their children and grandchildren. $1 / 5$ of the grandparents were very critical towards their grandchildren. They pointed out that grandchildren have narcissism and little interest to culture. Reflection of all negative characteristics occurs amongst all generations (also in their personal testimonials).

Then a question was raised: if and how much the generations want to resemble other generations. In the middle generation there are 1/3 of those who want to familiarise themselves with younger people, explaining that younger generation lives more easily and simply than they do. The most admirable ability is how young people have the capability of managing computers. Other middle-aged respondents claim the next generation has to look like the generation before and has to live in their developing tempo. 2/5 of the younger generation want to be similar to the older generations by saying that relationships were more personal in the past, people talked directly and without technical devices. They were more approachable and kind-hearted; also, they could value what they had. The middle generation thinks that young people live in sufficiency and they do not know how to appreciate that situation. There is a paradox that in the young people's opinion the petition of women and men equality in society is negative. They explain it saying that it ruined the specifics of a tender status of women. Other $3 / 5$ do not want to be similar with the older generations, emphasizing that young people see the world differently. Thus, it can be said that generations are not homogeneous by their angles; on the other hand, they also want to see positivity in various occurrence.

Discussing the problems between generation conflicts, there were only $1 / 5$ of the young people with opinion that such kind of concept does not exist. They think that the conflict resources can only be political views, attitude towards spiritual values, ideas of important characteristic features, specific needs of different generations, new technology that shapes a new type of a person, who has to adapt 


\section{SHS Web of Conferences}

to new challenges, also, different age, while those values were designed. Young people claim that their parents were born during the USSR regime and because of that they have problems in communication and expressing themselves. The differences between generations also affect music, cinema, fashion, even food. The favours of food are similar between the middle and old generation. This is different amongst the middle and young generation, where only $2 / 5$ of the cases the preferences are alike. A quarter of young generation prefer fast food, others like food that include more vegetables and less meat (they admit that their parents eat unhealthy food - rich meat and little vegetables).

$3 / 4$ of the youth believe that there is no such thing as generation conflict and they explain it with increased tolerance in society. The elderly people try to adapt their values according to the time, even if they do not understand all the details and they would have done it differently themselves, but they do not dispute. Conflict occurs when the relationships are based on labelling and stereotyping (youth is stupid, adults flawless), or the older generations are strictly fastened with their views and deny to take the younger generation as it is. The young people have also started to regard the elderly with more tolerance. Without exception all of the young people affirm that there is intergenerational solidarity in their parents' families and it is based on love and respect. The younger generation help their grandparents in their housework (greenhouse, garden). They will not even discuss the need for help - they say that they will not leave anyone in trouble and they know that they also will get help if needed.

To decline the differences, the older generation finds it important to love, trust and honour their children and not press those things upon their children and it is necessary to have an ability to be selfcritical. Other generations share those beliefs, emphasizing communication, the necessity of empathy and compromise, also ability to honour other person's position and honour it. Parents also think that until younger generations give them the opportunity to develop and they reply by giving youth an opportunity to receive experience, there is a regular progress. There are family traditions, which are passed from generation to generation, and help to build the togetherness between generations. There are certain traditions in every family: one of them was celebrating birthdays together with grandparents, another was to celebrate other family occasions. There were $1 / 6$ of the families which celebrated their family reunion.

For the older generation the solidarity between different generations is based on the mutual assistance: taking care of the grandchildren, common interests, love, respect and understanding each other. The middle generation sees the resources of solidarity in family welfare and solving mutual problems, trust, similar values; being informed which interests their kids have; lifelong education and openness towards the world; money, doing sports, doing something together during the spare time. Also, the middle generation finds it important to keep steps with the youth, but not losing their beliefs at the same time. The young generation admits that the reciprocal trust, interest and love, talking about success, travelling, household and money are significant solidarity resources.

The solidarity between generations also influences taking care of the children and the breeding values. The research showed that the foundation of childrearing among both grandparents and parents are the universal values: family, love, safety of a family, goodness and caring. At the same time the role of grandparents' individualism and autonomy have also started to acquire relative importance. The results of the study show that the dominating nuclear family model is leaving fewer opportunities to communicate with the whole family. There are only few of those grandparents who are living with their adult children and grandchildren. $2 / 3$ of the grandparents are employed people who will not give up their active and independent lifestyle for their grandchildren. Today a grandparent is much younger of age, which is favoured by the increase in the retirement age. 'She' is hard-working, nimble, mobile and sociable. In reality it is hard for Her to take up the new role, because it is associated with aging. She looks after the grandchildren according to the needs of a young family, only one tenth of the grandparents are bound daily with the upbringing of their grandchildren. Grandparents mostly have a role of family guests, who have no direct obligations or responsibilities in childrearing. When taking care of their grandchildren, grandparents value emotional satisfaction: to feel useful, to be part of the youth social network.

$$
\text { 00014-p.8 }
$$




\section{Int. Conf. SOCIETY. HEALTH. WELFARE.}

What grandparents like most is walking with grandchildren in the woods, helping in homework, playing together (a third of the respondents admit that). A quarter of grandmothers read fairy-tales to their grandchildren. In one fifth of the families grandparents do together gardening, watch children programmes on TV and go to the woods to pick berries and mushrooms. Less than a fifth of grandparents talked about their childhood and liked to sing to their grandchildren. Tourist trips, hiking, sports, theatre, cinema, playing an instrument were not popular. The younger generation help their grandparents in their housework (greenhouse, garden). They will not even discuss the need for help - they say that they will not leave anyone in trouble and they know that they also will get help if needed.

If people live together with grandparents, their main duties are cooking, cleaning, doing the laundry, fixing things and dish washing. In the single-parent families grandparents take part in the upbringing more intensively and they take up the role as a parent. Because of the economic crisis many grandparents feel responsible for the economic well-being of their children and grandchildren and they try to help them economically when possible - a whole one third of them are helping out with money, many of them help with home-made canned food and vegetables.

The young people see the image of a grandparent today with their life wisdom, but also in their contemporary clothing and their life-style, where the grandparents are not afraid to learn from the young, especially in the area of information technology. The elderly people try to adapt their values according to the time, even if they do not understand all the details and they would have done it differently themselves, but they do not dispute. The young people have also started to regard the elderly with more tolerance.

\section{Discussion and conclusions}

The data from the research reveal that among the Russians living in Estonia the core of values is formed by universal vital values, such as children and grandchildren, the safety of a family and health. At the same time the family culture of modern Russians living in Estonia has been influenced by the fundamental changes in social environment, economic and political affairs and in the general quality of life. It can be declared that as the process of changes in upbringing by the generation of parents have shaped a more informed, autonomous, self-trust, individualistic and mobile person.

Both the generation of grandparents and parents admit that their experience does not work in the conditions of the changed world and they consider the different behaviour of the younger generation as natural.

On the other hand a modern family prefers to live separately. Previously there were extended families where many generations lived together. Today this is history. This was the reason of weakening of the links with the older generation. The role of the traditional grandparent has changed its content. The grandparent's role is no more accompanied by the concrete obligations as before, but this role has more emotional value. At the same time it is important for grandparents to get emotional satisfaction in their communication with grandchildren. Emotional link with grandmothers is also positive for grandchildren, which is proved by grandmother's positive image in the eyes of grandchildren.

Individualistic tendencies are characteristic only not to the younger generation but their role has increased also in other generations. As the result of the upbringing given by the previous generation, now a new generation grows up who is more prepared to tolerate the influence of new environment, but who care less about the traditional standards and rules. At the same time other generations have changed as well because they want to develop with others.

Generations see the world differently enough. Older generation is more tuned into stability and the younger to protest towards current standards. Parents and grandparents were both positive about that as they claimed that conflicts between parents and children weaken with time and they understand their parents. Nevertheless, mostly the young people admit the presence of a generation gap, but they also associate it with puberty when the relations between parents and children were completely different, and they confirmed that when it passed they started to understand their parents much better. They saw

$$
\text { 00014-p.9 }
$$




\section{SHS Web of Conferences}

the image of a nowadays grandparent in their life wisdom, but also in their contemporary clothing and their life-style, where the grandparents were not afraid to learn from the young, especially in the area of information technology.

Still the study had not confirmed any materialistic or pragmatic tendencies in ties between generations. Solidarity between generations in families is revealed both in exchanges of instrumental and financial assistance, support between family members and feelings of emotional closeness. Despite the differences in behaviour and views all three generations acknowledged the solidarity with other generations and valued it.

\section{References}

[1] Bengtson, V.L., Oyama P.S. Intergenerational Solidarity: Strengthening Economic and Social Ties. New York: United Nations Headquarters, 2007. http://www.un.org/esa/socdev/unyin/ documents/egm_unhq_oct07_bengtson.pdf (10.08.2012)

[2] Silverstein, M. \& Bengtson, V.L. Intergenerational Solidarity and the Structure of Adult ChildParent Relationships in American Families. // American Journal of Sociology, 1997, Vol. 103, No. 2. - pp. 429-460 http://www.techsociety.com/articles/AJSv103p429.pdf (23.02.2013)

[3] Inglehart, R. The Silent Revolution in Europe: Intergenerational Change in Post Industrial Societies. // American Political Science Review, 1971, Vol. LXV, No. 4, Dec.- pp. 991-1019

[4] José Ortega y Gasset. Stanford encyclopedia of philosophy, 2011 http://plato.stanford. edu/entries/gasset/ (23.07.2012)

[5] Kovacz, D. \& Maggard, S.W. The Human Face of Political, Economic and Social Change in Eastern Europe. // East European Quaterly, 1993, No. 3 - pp. 3-10

[6] Kraav, I. Väärtused erinevate põlvkondade elus. - Väärtuskasvatus. Tartu Ülikooli pedagoogika osakonna väljaanne nr. 6. Tartu: TÜ, 1998 - lk. 72-94

[7] Maslow, A.H. Motivation and personality. $2^{\text {nd }}$ ed. New-York: Harper \& Row Publishers, 1970

[8] McLuhan, M. The Guttenberg Galaxy: the Making of Typographical Man. Toronto: University of Toronto Press, 1995

[9] Schutz, A. Collected papers, II. Studies in social theory. A. Brodersen (ed.). Hague: Martinus Nijhoff, 1964. - 159-178

[10] Tammaru, T. Venelased Eestis: ränne ja kohanemine. Tallinn: Sisekaitseakadeemia, 1999

[11] Toffler, A. The Third Wave. Toronto, NY, London, Aukland: Baantam Books, 1982

[12] Weber, A. Võimu ja religiooni sotsioloogiast. Vagabund, 2002

[13] Громыко М. Мир русской деревни. Москва: Молодая Гвардия, 1991

[14] Kастельс М. Информационная эпоха. Экономика, общество и культура. Москва: CEU, 2000

[15] Коровицина Н. Среднее поколение в социокультурной динамике Восточной Европы второй половины ХХ века. Москва: Логос, 1999

[16] Коул М. Культурно-историческая психология. Наука будущего. Москва: КогитоЦентр. Институт психологии РАН, 1997

[17] Ровнер А. Третья культура. Санкт-Петербург: Медуза, 1996

[18] Самохвалова В.И. Образ культуры минувшего века. Доминанты и тенденции. // Век XX - анфас и профиль: Размышления о столетии, ставшем историей. Москва: Новый Век, 2001

[19] Толстых А. Опыт конкретно-исторической психологии личности. СанктПетерᄀбург: Алетейя, 2000

[20] Туманов С. В. Культурные миры молодых россиян: три жизненные ситуации. Москва, Издательство МГУ, 2000 